Nat. Hazards Earth Syst. Sci. Discuss., https://doi.org/10.5194/nhess-2018-1

Manuscript under review for journal Nat. Hazards Earth Syst. Sci.

Discussion started: 12 February 2018

(c) Author(s) 2018. CC BY 4.0 License.

\title{
Estimation of hazard assessment by FINSIM for west coast and son narmada faults
}

\author{
Shivamanth Angadi ${ }^{1}$, Mayank Desai ${ }^{2}$ \\ ${ }^{1}$ Research Scholar, Dept. of Applied Mechanics, SVNIT, SURAT-395007, India \\ $5 \quad{ }^{2}$ Assistant Professor, Dept. of Applied Mechanics, SVNIT, SURAT-395007, India
}

Correspondence to: Shivamanth Angadi (shiva05cv@gmail.com)

\begin{abstract}
The Seismic hazard study was carried out for Maharashtra state, Bombay (Latitude 18.940 N, Longitude 72.840E). In the present study the geological fault is known as West coast fault and Son Narmada Faults were studied and used for the earthquake simulation, extended finite fault method originally FINSIM given by M. Atkinson (1998), was used to simulate an earthquake of $6.5 \mathrm{Mw}$. The soil classification was carried out by the Shear wave velocity and the relation between Shear wave velocity and SPT valves was also recommended by Sumedh Y. Mhaske (2011), since the Mumbai has been formed by the conglomeration of various islands which has come together to form a single landmass. The soil investigation suggested that Most of the region comes under the Class D and C for the worst case simulation we have used the site class D. The peak 15 ground accelerations (PGA) vary from 0.03g to 0.133g. While coming to zonal area IS1893:2002 still consider the Mumbai city under zone III with $\mathrm{Z}$ value of 0.16 and the result have been compared with the analysis done by many research in the same area.
\end{abstract}

\section{Introduction}

Now-a-days millions of people in the different part the world live with a significant risk to their lives and property from earthquakes. Billions of dollars of public infrastructure are continuously at risk of earthquake damage. These risks are not unique to the United States, Japan, or any other country. Earthquakes are global phenomenon and a global engineering problem. Some specific regions have been witnessing earthquakes repeatedly but it doesn't mean that some regions are earthquake free even the peninsular India so called stable region has witnessed the earthquakes of large magnitude. The following past earthquakes have made the government and the research institutes to work towards the disaster mitigation programme or the disaster management program, September 30th 1993 khillari, May 22nd Jabalpur, March 29th 1999 and the famous and most disastrous Bhuj earthquake on 26th January 2001.

To understand the evolution of seismic hazard estimation or the peak ground acceleration estimation, mathematical theories were used in order to simulate or represent the seismic wave propagationby the past researchers. As per the present region of study is considered lot of work has been done by many researchers using deterministic and probabilistic seismic hazard 
Nat. Hazards Earth Syst. Sci. Discuss., https://doi.org/10.5194/nhess-2018-1

Manuscript under review for journal Nat. Hazards Earth Syst. Sci.

Discussion started: 12 February 2018

(c) Author(s) 2018. CC BY 4.0 License.

(c) (i)

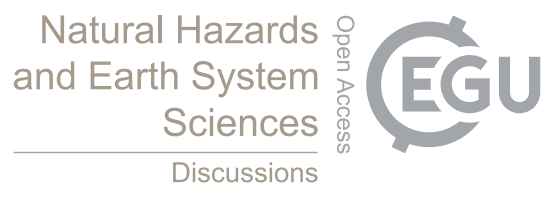

estimation, an attempt has been made in the present study to simulate earthquake in the West Coast and son narmada faults using Extended finite fault modeling or FINSIM program.

\section{The Study Area and Geographical Details}

The present research work the seismic sources within the radius of about 300km are considered with Mumbai city (latitude $5 \quad 18.940 \mathrm{~N}$, longitude $72.840 \mathrm{E}$ ). The control region covers latitudes from 16.00 to $22.000 \mathrm{~N}$ and longitudes from 69.90 to $75.900 \mathrm{E}$ and includes major part of western Maharashtra, southern Gujarat and Union Territory of Daman. The considered area falls under zone II-IV. Mumbai and Daman (Union Territory also the southern part of Gujarat) lie in zone III, Warna and Koyna region on western side of Maharashtra lie in zone IV, rest of rest of western side of Maharashtra within the control region falls in zone II and III.

\section{Methodology}

Finite source modelling is been an important stage of ground motion prediction process near the epicenter of the large earthquake. In most of the studies the entire fault is discretized into small elements, and each small element is treated as small source, and the radiation or the energy given or dissipated by all such sources is summed with the proper delay in time. The rupture begins at the given point or at hypocenter and propagates with constant velocity and it will trigger sub-sources as 15 soon as it reaches them. This simple kinematic phenomenon applied on all sub faults differ chiefly on how the path effects and sub-source spectra are defined. The sub-events which are modeled out of the faults are characterize as "stochastic" $\omega^{2}$ sources and the empirical distance dependent duration, attenuation models and geometric spreading are used to define and describe the path effects. This stochastic method has been successfully used to predict earthquakes that could be treated as point sources, the aim of the FINSIM or the EXSIM is to extend this technique to large faults and The amplifications can be used directly in the stochastic model for simulating earthquake ground.

\section{Fault Details and Earthquake Model Parameters}

West coast fault have witnessed an earthquake of magnitude Mw 5.2 in the year 1993 also according to Raghukanth and Iyengar (2006), Seismic hazard of Mumbai region is controlled by west coast fault. As mentioned earlier the geometrical and geological details of both the faults are taken from seismotectonic map of India published by GIS. The geometrical parameters are given in Table no 1, 2and 3. 
Nat. Hazards Earth Syst. Sci. Discuss., https://doi.org/10.5194/nhess-2018-1

Manuscript under review for journal Nat. Hazards Earth Syst. Sci.

Discussion started: 12 February 2018

(c) Author(s) 2018. CC BY 4.0 License.

\section{Results and Discussion}

Entire Mumbai was divided into the grids of size $0020^{\prime \prime} \mathrm{X} 002{ }^{\prime} 0^{\prime \prime}$ Show in Fig 1 which divides the area into $5 \mathrm{kmby} 5 \mathrm{~km}$ square grid the Spectral accelerations and acceleration time history are evaluated at the intersection of the grid point there are about 69 points. Other than these 69 grid points the results are also calculate for the important site and areas in the Mumbai

5 city. The coordinates of the important places and cities are given in Table 4 and 5 and the results of the peak ground acceleration and spectral acceleration at the important sites and places are tabulated in Table 6.

In Fig 2 (a) and (b) are the contour maps of PGA values due to West Coast fault at important sites and places which are given in Table 4 and 5. The central Mumbai is highly vulnerable, mainly the region from Chatrapathi Shivaji International Airport to Baba Atomic Research Centre (BARC). The PGA values of West coast fault with $0.035 \mathrm{~g}$ to $0.059 \mathrm{~g}$, Sarika D and

10 Chaoudary D, (2014), have carried out the seismic hazard analysis for the Mumbai city using deterministic and probabilistic methods, Fig 2 (c) and (d) shows the comparison of the contour maps of PGA values since the author have calculated the PGA values at bed rock level, by DSHA method PGA values vary from 0.17 to $0.626 \mathrm{~g}$ and by PSHA method 0.17 to $0.37 \mathrm{~g}$ since the site amplification factor are also considered in present work the PGA values vary between 0.36 to $0.565 \mathrm{~g}$. Fig 3 shows the graphs of Spectral acceleration Vs time at important site and place.

\section{Conclusion}

The present study is an attempt to simulate the earthquake at the geological faults near the study area using Extended Finite fault Method. The seismic hazard was first estimated at bed rock level and then with the incorporation of soil amplification the hazard was estimated at the surface. The peak ground accelerations (PGA) vary from $0.03 \mathrm{~g}$ to $0.133 \mathrm{~g}$. (g) values for the entire grid points. Raghukanth and Iyengar also calculated the PGA (g) values for Mumbai region by PSHA method, PGA

20 (g) value was found out to be 0.28 few sites with shear velocity between $760-1500 \mathrm{~m} / \mathrm{s}$, as we have considered the soft soil condition to have worst case scenario we have got higher value. Similarly spectral acceleration values vary from $0.1 \mathrm{~g}$ to $0.44 \mathrm{~g}$ for Class D site in our case the $\mathrm{Sa} / \mathrm{g}$ values vary from $0.21 \mathrm{~g}$ to $0.7 \mathrm{~g}$ for the most of the class.

\section{References}

Kramer S L (1996), Geotechnical earthquake engineering, In Prentice-Hall international series in civil engineering and engineering mechanics. Prentice-Hall, New Jersey.

Sarika S Desai and Deepankar Choudhury (2013), "Deterministic Seismic Hazard Scenario for Mumbai City" Proceedings of Indian Geotechnical Conference December Roorkee 2013, 22-24.

Boore, D. M. (1996). SMSIM--Fortran programs for simulating ground motions from earthquakes: version 1.0, U.S. GeoL Surv. Open-File Rept. 96-80-A, 96-80-B, 69 pp. 
Nat. Hazards Earth Syst. Sci. Discuss., https://doi.org/10.5194/nhess-2018-1

Manuscript under review for journal Nat. Hazards Earth Syst. Sci.

Discussion started: 12 February 2018

(c) Author(s) 2018. CC BY 4.0 License.

(c) (i)

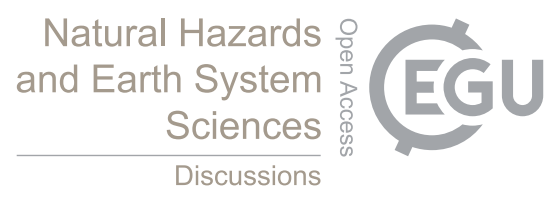

B K Rastogi and A G Chhatre (2014), “ Seismoteconic Investigations for siting Nuclear Power Plants, Assessment of Design Basis Ground Motion and Tsunami Hazard”, Journal of Earthquake science and Engineering, 1, 93-109.

David M. Boore and William B. Joyner (1997), "Site Amplifications for Generic Rock Sites"Bulletin of the Seismological Society of America, 87, 2, 327-341, doi:10.1.1.503.4738.

5 Indian Standard 1893 (Part I), "Criteria for Earthquake Resistance Design of Structures", Part-1: General Provisions and Buildings, Fifth revision, Bureau of Indian Standards, New Delhi, (2002).

Iyengar, R.N. and Raghukanth, S.T.G., “Attenuation of strong ground motion in peninsular India”, Seismological Research Letters, vol. 75(4), 530-540, doi=10.1.1.927.4836.

Sarika S Desai and Deepankar Choudhury, "Spatial variation of probabilistic seismic hazard for Mumbai and surrounding 10 region” Nat Hazards 71, 1873-1898, doi: 10.1061/(ASCE)NH.1527-6996.0000177.

Pallabee Choudhury, Sumer Chopra, Ketan Singha Roy, B K Rastogi (2013), “A review of strong motion studies in Gujarat State of western India" Nat Hazards 71, 1241-1257, doi: 10.1007/s11069-013-0962-x.

Sumedh Y. Mhaske and Deepankar Chaoudary (2011)“Geospatial contour mapping of shear wave velocity for Mumbai city" Natural Hazard, 59, 317-327, doi: 10.1007/s11069-011-9758-z.

15

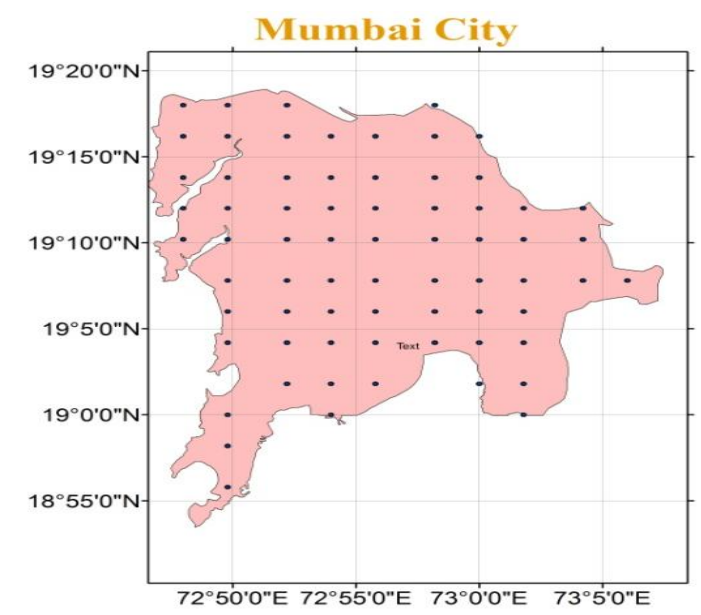

Fig. 1: Mumbai city with grid points at $5 \mathrm{kmX5km}$. 
Nat. Hazards Earth Syst. Sci. Discuss., https://doi.org/10.5194/nhess-2018-1

Manuscript under review for journal Nat. Hazards Earth Syst. Sci.

Discussion started: 12 February 2018

(c) Author(s) 2018. CC BY 4.0 License.
Natural Hazards 웅 and Earth System Sciences

Discussions

\section{(c) (i)}

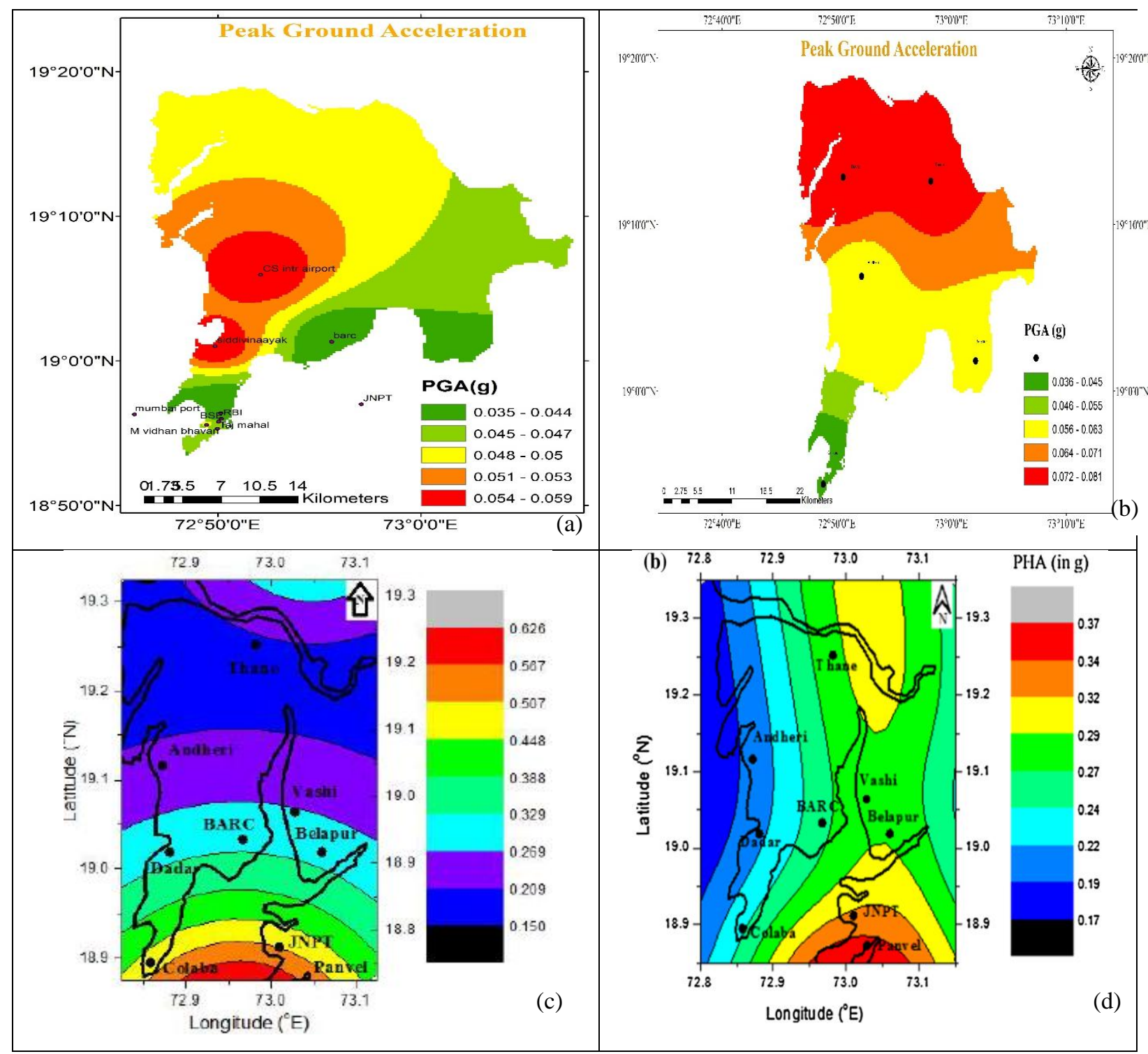

Fig. 2: Contour maps of PGA values at important sites and places of West Coast Fault and Comparison. 
Nat. Hazards Earth Syst. Sci. Discuss., https://doi.org/10.5194/nhess-2018-1 Manuscript under review for journal Nat. Hazards Earth Syst. Sci.

Discussion started: 12 February 2018

(c) Author(s) 2018. CC BY 4.0 License.

\section{(c) (i)}
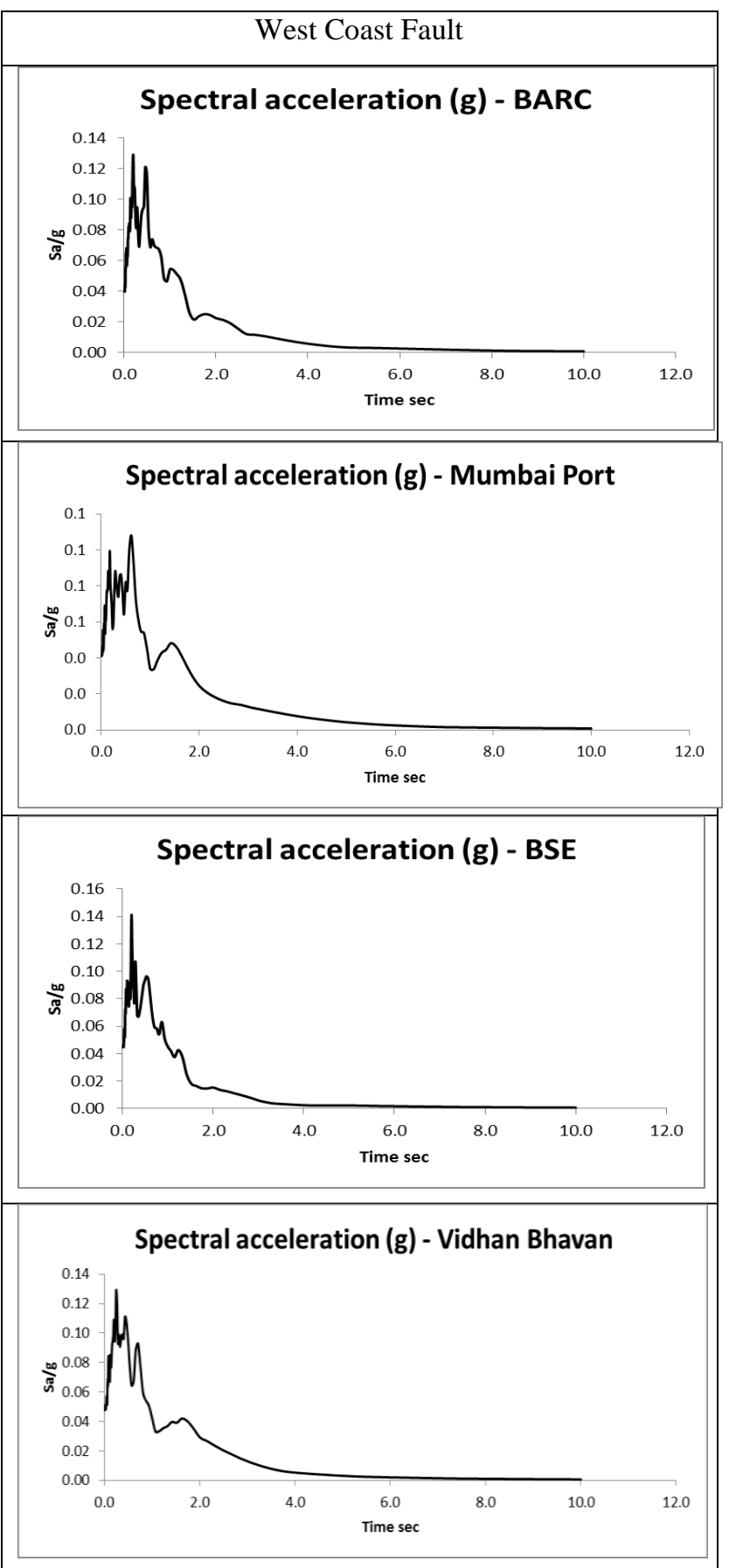
Nat. Hazards Earth Syst. Sci. Discuss., https://doi.org/10.5194/nhess-2018-1 Manuscript under review for journal Nat. Hazards Earth Syst. Sci.

Discussion started: 12 February 2018

(c) Author(s) 2018. CC BY 4.0 License.

\section{(c) (1)}
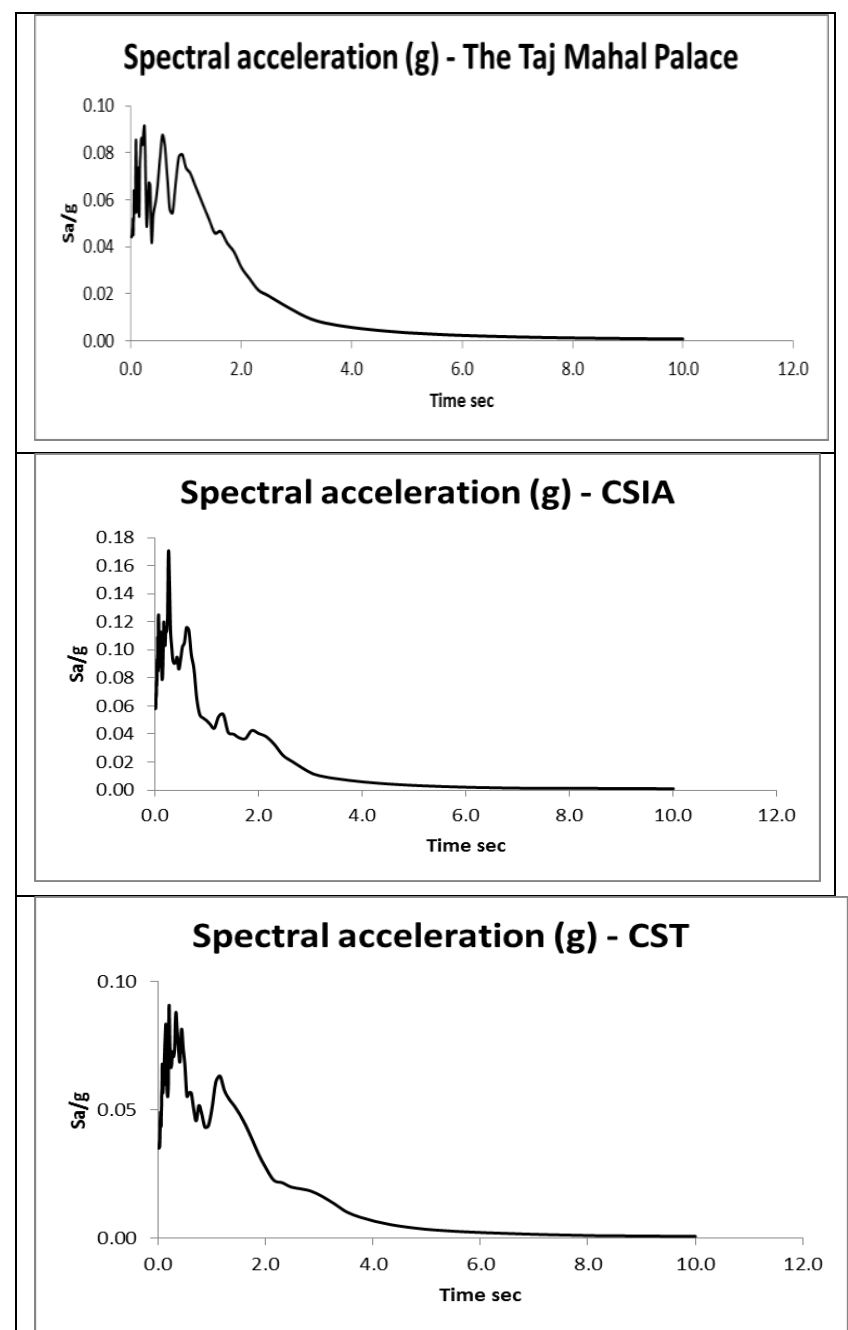

Spectral acceleration (g) - Siddi vinayak Temple

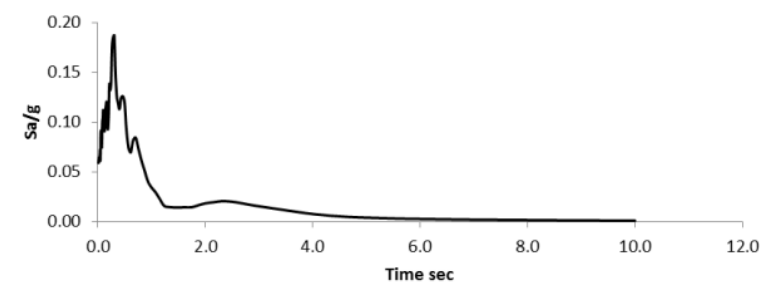


Nat. Hazards Earth Syst. Sci. Discuss., https://doi.org/10.5194/nhess-2018-1 Manuscript under review for journal Nat. Hazards Earth Syst. Sci.

Discussion started: 12 February 2018

(c) Author(s) 2018. CC BY 4.0 License.

\section{(c) (1)}
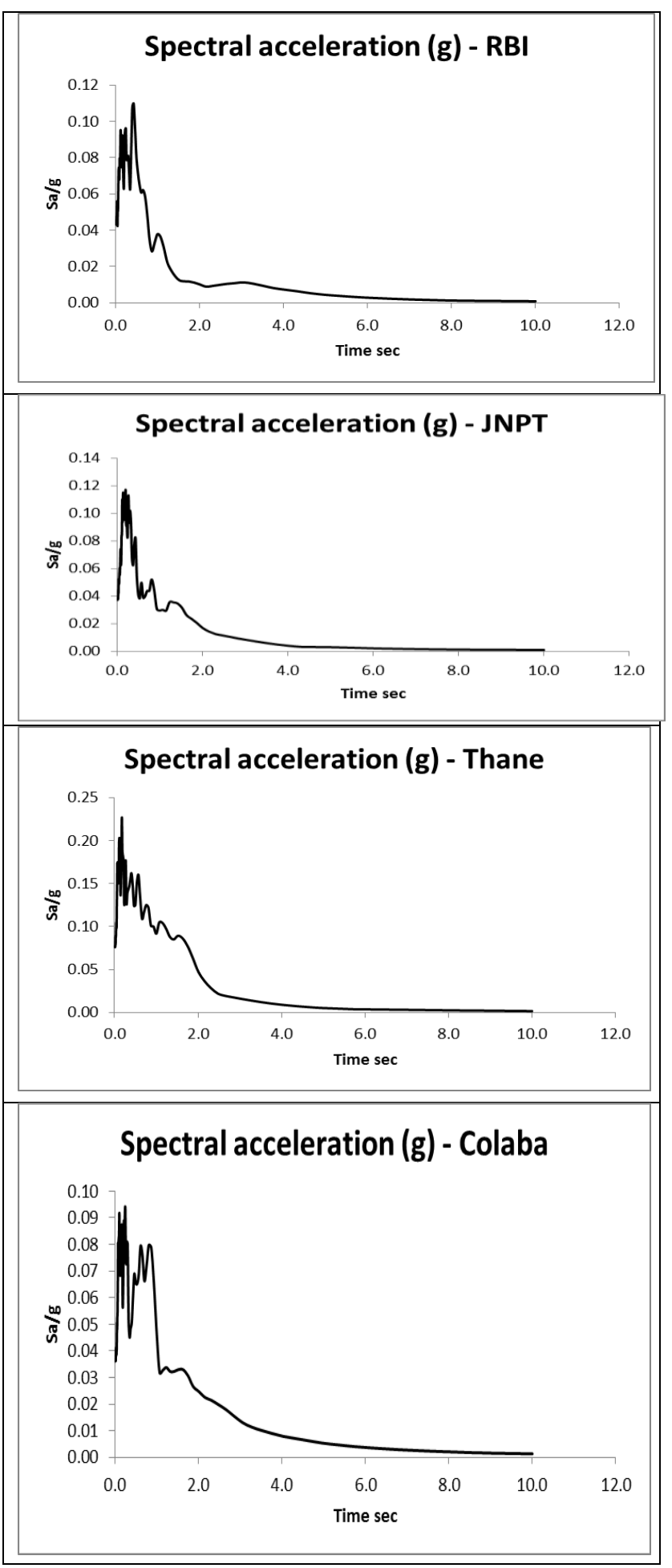
Nat. Hazards Earth Syst. Sci. Discuss., https://doi.org/10.5194/nhess-2018-1 Manuscript under review for journal Nat. Hazards Earth Syst. Sci.

Discussion started: 12 February 2018

(c) Author(s) 2018. CC BY 4.0 License.

\section{(c) (1)}
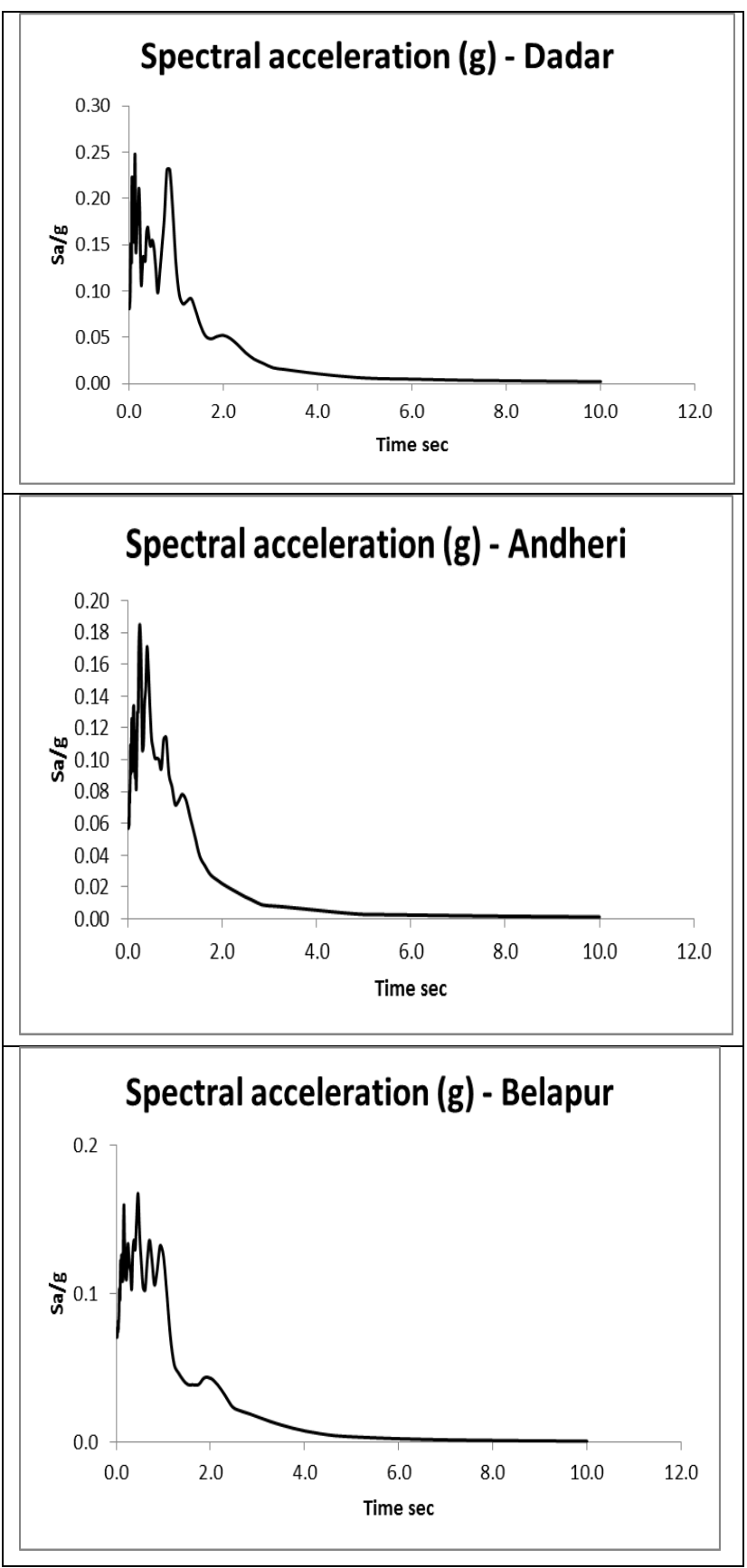

Fig 3. Spectral acceleration graphs

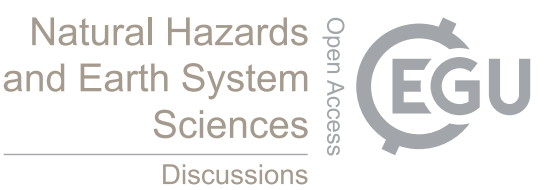


Nat. Hazards Earth Syst. Sci. Discuss., https://doi.org/10.5194/nhess-2018-1

Manuscript under review for journal Nat. Hazards Earth Syst. Sci.

Discussion started: 12 February 2018

(c) Author(s) 2018. CC BY 4.0 License.

(c) (1)

Table : 1 Geometrical Fault details

\begin{tabular}{|c|c|c|c|c|c|c|}
\hline \multirow{2}{*}{$\begin{array}{c}\text { Name of the } \\
\text { fault }\end{array}$} & \multicolumn{2}{|c|}{ Start co-ordinate } & \multicolumn{2}{c|}{ End co-ordinate } & $\begin{array}{c}\text { Distance } \\
\text { Km }\end{array}$ & $\begin{array}{c}\text { Earthquake } \\
\text { Mw }\end{array}$ \\
\cline { 2 - 5 } & Latitude & Longitude & Latitude & Longitude & & 5.2 \\
\hline West Coast & 19.99 & 72.85 & 18.008 & 73.20 & 370.5 & 5 \\
\hline
\end{tabular}

Table 2 : Geological Fault details

\begin{tabular}{|c|c|}
\hline \multicolumn{2}{|c|}{ Weast Coast Fault } \\
\hline Earthquake date & $12-08-1993$ \\
\hline Location & Lat 17.03 Long 73.65 \\
\hline Magnitude and depth & Mb-4.9, Depth-32 Km \\
\hline Type & Np2 \\
\hline Strike & $173^{0}$ \\
\hline Dip & $58^{0}$ \\
\hline
\end{tabular}

5 Table 3 : Model Parameters used for the simulation of ground motion in the present study for Weast coast fault

\begin{tabular}{|c|c|c|}
\hline Magnitude & 6.5 & Present work \\
\hline Latitude, Longitude & $19.99^{0} \mathrm{~N}, 72.85^{0} \mathrm{E}$ & Present work \\
\hline Hypocenter depth & $15 \mathrm{~km}$ & Present work \\
\hline Fault strike Dip & $173^{0}, 58^{0}$ & Present work \\
\hline Fault length width & $25 \mathrm{~km}, 12 \mathrm{~km}$ & Present work \\
\hline Slip Distribution & Random & Present work \\
\hline No faults along strike, dip & 25,12 & Present work \\
\hline Location of the hypocenter on fault & 1,1 & Hard rock \\
\hline plane & & Hard rock \\
\hline Shear wave velocity & $3.6 \mathrm{~km} / \mathrm{s}$ & Present work \\
\hline Density & $2.8 \mathrm{~g} / \mathrm{cm}^{3}$ & Present work \\
\hline Stress drop & 140 & Bodin et al 2004 modified by Sumeer \\
\hline Kappa & 0.016 & \\
\hline Geometric Spreding & $1 / R-R \leq 40 \mathrm{~km}$ & \\
\hline
\end{tabular}


Nat. Hazards Earth Syst. Sci. Discuss., https://doi.org/10.5194/nhess-2018-1

Manuscript under review for journal Nat. Hazards Earth Syst. Sci.

Discussion started: 12 February 2018

(c) Author(s) 2018. CC BY 4.0 License.

(c) (1)
Natural Hazards and Earth System

Sciences

Discussions

\begin{tabular}{|c|c|c|}
\hline & & chopra 2012 \\
\hline & $1 / R^{0.5}-(40 \leq R \leq 80 \mathrm{~km})$ & \\
\hline & $1 / R^{0.55}-(R \geq 80 \mathrm{~km})$ & \\
\hline Duration properties & $f_{c}^{-1}-(R<10 \mathrm{~km})$ & Atkinson and Boore (1995) \\
\hline & $f_{c}^{-1}+0.16 R-(10 \leq R \leq 70 \mathrm{~km})$ & \\
\hline & $f_{c}^{-1}+0.04 R-(130 \leq R \leq 1000 \mathrm{~km})$ & \\
\hline Attenuation relation & $84 \mathrm{f}^{0.65}$ & B K Rastogi and A G Chhatre (2014) $[4,9]$, \\
\hline Pulsing Percent & 50 & \\
\hline
\end{tabular}

Table 4 : Important sites

\begin{tabular}{|c|c|c|}
\hline Latitude & Longitude & site \\
\hline 19.02 & 72.93 & BARC \\
\hline 18.94 & 72.77 & Mumbai port \\
\hline 18.93 & 72.83 & BSE \\
\hline 18.93 & 72.82 & $\begin{array}{c}\text { M vidhan } \\
\text { bhavan }\end{array}$ \\
\hline 18.92 & 72.83 & Taj mahal \\
\hline 19.10 & 72.87 & CS intr airport \\
\hline 18.94 & 72.84 & CST rail \\
\hline 19.02 & 72.83 & $\begin{array}{c}\text { Siddivinaayak } \\
\text { Temple }\end{array}$ \\
\hline 18.93 & 72.84 & RBI \\
\hline 18.95 & 72.95 & JNPT \\
\hline
\end{tabular}

Table5 : Important places

\begin{tabular}{|c|c|c|}
\hline Latitude & Longitude & Place \\
\hline 19.21 & 72.97 & Thane \\
\hline 18.91 & 72.81 & Colaba \\
\hline 19.21 & 72.84 & Dadar \\
\hline 19.11 & 72.87 & Andheri \\
\hline
\end{tabular}


Nat. Hazards Earth Syst. Sci. Discuss., https://doi.org/10.5194/nhess-2018-1

Manuscript under review for journal Nat. Hazards Earth Syst. Sci.

Discussion started: 12 February 2018

(c) Author(s) 2018. CC BY 4.0 License.

\begin{tabular}{|l|l|l|}
\hline 19.03 & 73.04 & Belapur \\
\hline
\end{tabular}

Table : 6 Peak ground acceleration and spectral acceleration values at important sites and places

\begin{tabular}{|c|c|c|c|c|c|}
\hline \multirow{2}{*}{ Site } & & & West coast Fault & West coast Fault & West coast Fault \\
\cline { 5 - 6 } & Latitude & \multirow{2}{*}{ Longitude } & \multirow{2}{*}{$\mathrm{PGA}(\mathrm{g})$} & $\mathrm{Sa} / \mathrm{g}$ & $\mathrm{Sa} / \mathrm{g}$ \\
\cline { 5 - 6 } & & & $0.2 \mathrm{sec}$ & $1.0 \mathrm{sec}$ \\
\hline BARC & 19.02 & 72.93 & 0.040 & 0.104 & 0.054 \\
\hline Mumbai Port & 18.94 & 72.77 & 0.041 & 0.074 & 0.034 \\
\hline BSE & 18.93 & 72.83 & 0.045 & 0.100 & 0.045 \\
\hline M vidhan bhavan & 18.93 & 72.82 & 0.048 & 0.101 & 0.043 \\
\hline Taj mahal & 18.92 & 72.83 & 0.044 & 0.080 & 0.074 \\
\hline CS intr airport & 19.10 & 72.87 & 0.058 & 0.107 & 0.050 \\
\hline CST rail & 18.94 & 72.84 & 0.035 & 0.069 & 0.051 \\
\hline Sdiddivinaayak Temple & 19.02 & 72.83 & 0.059 & 0.118 & 0.034 \\
\hline RBI & 18.93 & 72.84 & 0.043 & 0.084 & 0.038 \\
\hline JNPT & 18.95 & 72.95 & 0.037 & 0.098 & 0.030 \\
\hline Thane & 19.21 & 72.97 & 0.076 & 0.171 & 0.092 \\
\hline Colaba & 18.91 & 72.81 & 0.036 & 0.081 & 0.047 \\
\hline Dadar & 19.21 & 72.84 & 0.081 & 0.171 & 0.130 \\
\hline Andheri & 19.11 & 72.87 & 0.057 & 0.123 & 0.072 \\
\hline Belapur & 19.03 & 73.04 & 0.057 & 0.104 & 0.101 \\
\hline
\end{tabular}

